\title{
The use of high-flow nasal oxygen in COPD patients
}

\author{
This article was published in the following Dove Press journal: \\ International Journal of COPD \\ 16 September 2016 \\ Number of times this article has been viewed
}

\author{
Pedro Silva Santos' \\ Antonio M Esquinas ${ }^{2}$ \\ 'Pulmonology Unit, Centro \\ Hospitalar e Universitário de \\ Coimbra - Hospitais da Universidade \\ de Coimbra, Coimbra, Portugal; \\ ${ }^{2}$ Internsive Care Unit, Hospital \\ Morales Meseguer, Múrcia, Spain
}

\section{Dear editor}

High-flow nasal cannula (HFNC) oxygen therapy is an innovative and useful mode for the treatment of patients with respiratory failure. ${ }^{1-3}$ It delivers heated and humidified air providing higher and more expected gas flow rates and fraction inspired oxygen $\left(\mathrm{FiO}_{2}\right)$ than traditional oxygen therapy. ${ }^{2}$

We read the article by Bräunlich et $\mathrm{al}^{1}$ carefully and congratulate the authors on their study about the use of nasal high-flow therapy in COPD patients. There are, however, some limitations to the study that need to be considered.

First, this study has a small number of patients, particularly in groups A and $\mathrm{B}$, which in our opinion will affect the comparison of data with the group $\mathrm{C}$ that contains a greater variety of patients with more severe outcomes, including forced expiratory volume in 1 second and forced vital capacity. Second, as a study on mean airway pressure, it would be interesting to evaluate partial pressure of $\mathrm{CO}_{2}$ with higher flows.

Third, one of the aims of this study was to characterize changes in hypercapnia, so it is not correct to include nonhypercapnic patients. Fourth, it would be interesting to know the $\mathrm{FiO}_{2}$ that was given and whether the patients had domiciliary oxygen or noninvasive ventilation, as most of them are hypercapnic patients. Finally, regarding comfort and dyspnea scale, HFNC showed better results, which may increase its use when intolerant to noninvasive ventilation.

In short, HFNC is an interesting mode for the future treatment of COPD patients with respiratory failure, which may lead to larger and randomized trials to confirm this indication.

\section{Disclosure}

The authors report no conflicts of interest in this communication.

\section{References}

1. Bräunlich J, Köhler M, Wirtz H. Nasal highflow improves ventilation in patients with COPD. Int JChron Obstruct Pulmon Dis. 2016;11:1077-1085.

2. Roca O, Hernández G, Díaz-Lobato S, et al. Current evidence for the effectiveness of heated and humidified high flow nasal cannula supportive therapy in adult patients with respiratory failure. Crit Care. 2016;20:109.

3. Nishimura M. High-flow nasal cannula oxygen therapy in adults: physiological benfits, indication, clinical benefits, and adverse effects. Respir Care. 2016;61(4):529-541. 


\section{Author's reply}

Jens Bräunlich

Marcus Köhler

Hubert Wirtz

Department of Respiratory Medicine, University of Leipzig, Leipzig, Germany

Correspondence: Jens Bräunlich

Department of Respiratory Medicine, University of Leipzig,

Liebigstrasse 20, 04I 03 Leipzig, Germany

Tel +49 34l 97। 2450

Email jens.braeunlich@uniklinik-leipzig.de

\section{Dear editor}

We thank Dr Santos and Dr Esquinas for their interest in our work ${ }^{1}$ and appreciate the opportunity to further discuss our data.

The aim of our study was to clarify effects of nasal high-flow (NHF) therapy on airway pressure and other ventilatory parameters in COPD patients. As we observed relatively uniform changes previously, the number of patients was kept at a moderate level. We characterized changes in ventilatory patterns and showed flow-dependent effects in patients with COPD.

The three groups of patients were not significantly different with regard to forced expiratory volume in 1 second (FEV1) and FEV1/forced vital capacity (FVC) ratio. The hypercapnic group, in which patients were selected for hypercapnia, however tended to be somewhat more severely diseased and had a significantly lower FVC. We have compared hypercapnic patients and nonhypercapnic patients in groups A and $\mathrm{B}$ with regard to the described ventilatory parameters following the comment of Dr Santos and Dr Esquinas and did not observe differences. Taking into account our previous observations, ${ }^{2,3}$ we have no indication that hypercapnic patients would react differently compared to nonhypercapnic patients with COPD. However, as previously reported, the decline in partial pressure of $\mathrm{CO}_{2}\left(\mathrm{pCO}_{2}\right)$ will be more pronounced in patients with more extensive hypercapnia.,
Dr Santos and Dr Esqiunas were also interested to learn about the decrease in $\mathrm{pCO}_{2}$ with higher flow rates. Unfortunately, we recognized that most of our stable patients did not tolerate higher flow rates for periods over 2 hours. This is clearly different to the situation of acute respiratory insufficiency, where the distress is great and the benefit is immediate. ${ }^{5}$

We agree with Dr Santos and Dr Esquinas in that NHF is a powerful and very interesting tool for ventilatory support and appreciate their thoughtful comments. The majority of studies selected patients with acute respiratory insufficiency. The aim of our study was to demonstrate changes and potential benefits in hypercapnic COPD patients, in whom the effects of NHF are not yet well characterized.

We hope to shed more light on the question of NHF and hypercapnia with an ongoing study evaluating the effects of NHF versus noninvasive ventilation in hypercapnic COPD patients (NCT02007772, "NHF vs noninvasive ventilation in stable hypercapnia COPD patients", TIBICO trail).

\section{Disclosure}

JB received travel grants and equipment from TNI medical AG, MK declared no competing interests, and HW received presentation lecture fees from TNI medical AG. The authors report no other conflicts of interest in this communication.

\section{References}

1. Bräunlich J, Köhler M, Wirtz H. Nasal highflow improves ventilation in patients with COPD. Inter J Chron Obstruct Pulmon Dis. 2016; 11(1):1077-1085.

2. Bräunlich J, Beyer D, Mai D, Hammerschmidt S, Seyfarth H-J, Wirtz H. Effects of nasal high flow on ventilation in volunteers, COPD and idiopathic pulmonary fibrosis patients. Respiration. 2013;85(4):319-325.

3. Bräunlich J, Seyfarth H-J, Wirtz H. Nasal high-flow versus non-invasive ventilation in stable hypercapnic COPD: a preliminary report. Multidiscip Respir Med. 2015;10(1):27.

4. Maggiore SM, Idone FA, Vaschetto R, et al. Nasal high-flow versus venturi mask oxygen therapy after extubation. Effects on oxygenation, comfort, and clinical outcome. Am J Respir Crit Care Med. 2014; 190(3):282-288.

5. Frat J-P, Thille AW, Mercat A, et al. High-flow oxygen through nasal cannula in acute hypoxemic respiratory failure. $N$ Engl $J$ Med. 2015; 372(23):2185-2196.

Dove Medical Press encourages responsible, free and frank academic debate. The content of the International Journal of Chronic Obstructive Pulmonary Disease 'letters to the editor' section does not necessarily represent the views of Dove Medical Press, its officers, agents, employees, related entities or the International Journal of Chronic Obstructive Pulmonary Disease editors. While all reasonable steps have been taken to confirm the content of each letter, Dove Medical Press accepts no liability in respect of the content of any letter, nor is it responsible for the content and accuracy of any letter to the editor.

International Journal of COPD

Dovepress

\section{Publish your work in this journal}

The International Journal of COPD is an international, peer-reviewed journal of therapeutics and pharmacology focusing on concise rapid reporting of clinical studies and reviews in COPD. Special focus is given to the pathophysiological processes underlying the disease, intervention programs, patient focused education, and self management protocols.
This journal is indexed on PubMed Central, MedLine and CAS. The manuscript management system is completely online and includes a very quick and fair peer-review system, which is all easy to use. Visit $\mathrm{http} / / / \mathrm{www}$.dovepress.com/testimonials.php to read real quotes from published authors. 